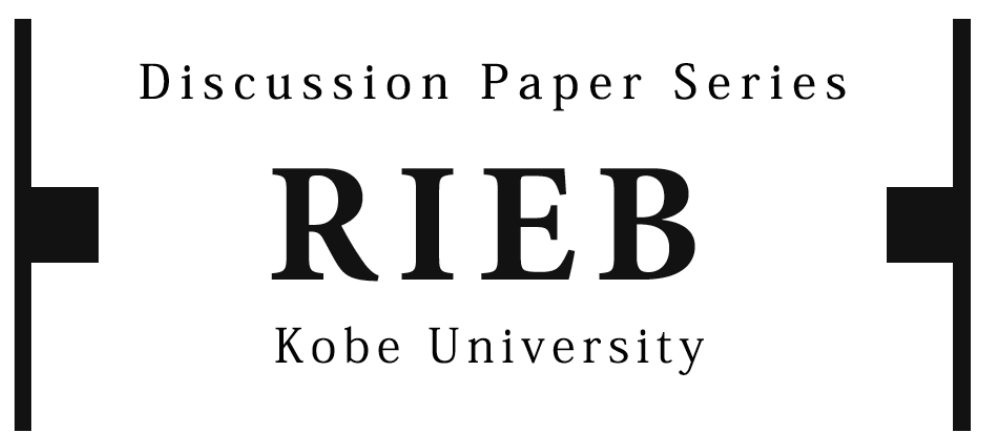

DP2019-15

\title{
Cultural Factors and Study Destinations of International Students*
}

\author{
Hao WEI \\ Ran YUAN \\ Laixun ZHAO
}

July 17, 2019

* The Discussion Papers are a series of research papers in their draft form, circulated to encourage discussion and comment. Citation and use of such a paper should take account of its provisional character. In some cases, a written consent of the author may be required.

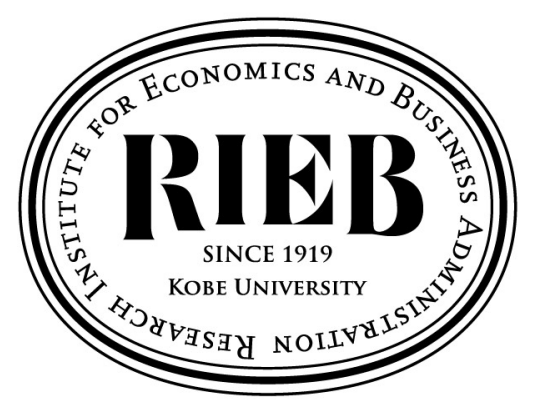

Research Institute for Economics and Business Administration

Kobe University

2-1 Rokkodai, Nada, Kobe 657-8501 JAPAN 


\title{
Cultural Factors and Study Destinations of International Students*
}

\author{
by \\ Hao Wei*, Ran Yuan* and Laixun Zhao ${ }^{\dagger}$
}

\begin{abstract}
We examine the role of cultural factors in attracting international students, using data of 102 countries from 2000 to 2015. Our results show that the export of cultural products is conducive to the increase of international students, and in particular, international students choose to study in developing countries whose official language and religious beliefs are different from their home countries, while they tend to go to developed countries with a common language. We also examine the features of international students in China and Chinese students in other countries. The policy implication from our study is that "soft power" such as a unique culture, common value and migration networks is important in attracting foreign students.
\end{abstract}

Keywords: Cultural factors, international students, cultural goods exports, migration networks, Chinese students abroad

JEL Classification: F16; I23

\footnotetext{
*: Dept. of International Economics, Beijing Normal University, Beijing, China;

$\dagger$ : Corresponding author, Research Institute for Economics \& Business, Kobe University, Kobe 657-8501, Japan, E-mail: zhao@rieb.kobe-u.ac.jp
} 


\section{Introduction}

Studying abroad is a common and universal phenomenon in the globalized economy. According to UNESCO statistics, the number of international students rose from 2 million in 2000 to 4.6 million in $2015 .{ }^{1}$ Together with the increasing scale, the trajectory of international students has also changed in the last few decades. While it has been historically characterized as going in one direction from developing countries to developed countries or from secondary developed countries to leading developed countries since the 1960s, the new pattern can be summarized as two-way circulation, i.e., mutual mobility between developing and developed countries, from the late 20th century (OECD, 2008). It is thus interesting and important to investigate the motivations for such student mobility and the causes of the changes.

Cultural proximity can be a critical dimension, but is hard to measure comprehensively. International students may experience a great deal of unfamiliarity in almost every aspect of their lives in the host countries because of the differences in language, culture, religion and educational systems. However, there is no existing unified framework that explains the role of cultural factors in shaping international student mobility.

In this paper, we attempt to accomplish this task, using data of 102 countries and regions for 2000-2015. Our main results indicate that the export of cultural products is conducive to the increase of international students, and the immigrant stock is beneficial for attracting international students from the source countries. Moreover, we find that international students choose to study in developing countries whose official language and religious beliefs are different from their home countries, while they tend to go to developed countries with a common language. We also examine the features of international students in China and Chinese students in other countries. The policy implication from our study is that "soft power" such as a unique culture, common value and migration networks is important in attracting foreign students.

\footnotetext{
${ }^{1}$ UNESCO Institute for Statistics, http://uis.unesco.org/
} 
Our study complements the existing literature in the following aspects: (1) So far most research chooses one country as the host country, and studies the bilateral student flow between this country and other countries. In contrast, we perform an overall analysis from a global perspective with many countries. (2) The existing literature mainly focuses on developed countries, while we fill the gap by including and focusing on developing countries, with special attention to China. (3) Most existing literature uses a single index to measure the cultural factors, by including only one of several potential factors such as language, religion and other variables, which cannot comprehensively reflect the implications of the full spectrum of culture. In contrast, the present paper measures cultural proximity from several key aspects: including timevariant and time-invariant factors, proposing a uniformed framework to comprehensively explore their role of culture in international student mobility, and especially incorporating the volume of various cultural-goods trade and the number of immigrants who can transmit foreign culture.

Some existing studies investigate the impacts of language proximity, religious proximity and migration networks on the destination choice of international students, but are markedly different from our analysis. For example, Chen and Barnett (2000) argue that international student exchanges based on linguistic relationships have become less significant, while economic and political development plays increasingly important roles; The "push-pull" framework studies the relationship between student outflow and the educational, economic and political dimensions in the host country (Mazzarol and Soutar, 2002); Racine, Villeneuve and Thériault (2003) investigate the case of students in Québec, Canada, finding that language is a decisive factor for international students flowing to this region; Park (2009) shows for South Korean students, academic expectations and the cultural environment are the most important factors in the selection of host countries; González, Mesanza and Mariel (2011) find that academic quality, cost of living, language, distance and other factors can significantly influence the number of international students in a country; Kondakci (2011) finds that climate, food preference, language, cultural experience and other factors can influence international students' choices in Turkish public universities; and 
Bouwel and Veugelers (2013) use shared language to measure cultural similarity, and find it has positive but insignificant impact on student mobility among 31 European countries. With regard to migration networks, Beine et al. (2014) find that migration networks, costs and the quality of universities are the most important factors, and Beech (2015) argues that social networks of friendship and kinship are critical determinants for students deciding to study overseas.

The rest of the paper is organized as follows: Section 2 presents the econometric model and explains the data; Section 3 reports our empirical results; Section 4 conducts robustness checks; and Section 5 concludes with some policy recommendations.

\section{Some basic facts of international student mobility}

\subsection{International students in higher education around the world}

The demand for a knowledge-based economy and highly skilled human resources drives the rapid expansion of higher education. The number of students engaged in tertiary education worldwide has exploded within a generation, rising from 97 million in 2000 to 231 million in 2015 (UNESCO, 2019). ${ }^{2}$ Since 2000, the gross enrollment ratio has risen by 29 percent in upper middle income countries, from $17 \%$ to $46 \%$, compared to 25 percent in Eastern and Southeastern Asia, and in Latin America and the Caribbean. At the same time, the number of students who choose to study abroad has increased from 1.3 million in 1990 to 4.7 million in 2015, demonstrating a new generation of young people eager to learn and expand their horizons. And this number is expected to further increase to as many as 8 million by 2025 (OECD, 2017). ${ }^{3}$

Table 1 shows inbound and outbound students of the top 10 countries in 2015 . In terms of geographical distribution, we find that, (a) English-speaking countries are among the biggest hosts of international students, with the United States (U.S.) enrolling about one-fifth of the world total, more than double that in the United Kingdom (U.K.), which is the No. 2 host. Specifically, about 37.67 percent of all

\footnotetext{
2 UNESCO (2018). Global Education Monitoring Report 2019, https://unesdoc.unesco.org/ark:/48223/pf000026 5866/PDF/265866eng.pdf.multi

3 OECD (2017). Education at a Glance 2017, https://www.oecd-ilibrary.org/education/education-at-a-glance-2017 _eag-2017-en
} 
international students enroll in four English-speaking countries (the U.S., the U.K., Australia and Canada). (b) Non-English speaking countries such as France and Germany are also large hosts, accounting for 5.0 and 4.7 percent respectively. (c) China has entered the market for students more recently, quickly becoming the third largest host and the largest developing destination for international students.

On the other hand, in terms of outbound students, we find that: (a) China is the largest origin country of international students, contributing about $17.1 \%$ of the world total, more than three times than those from India which is the second largest origin country. (b) Asian students studying in developed countries make up a large share. In 2015, the top three largest origin countries are in Asia, namely China, India and the Republic of Korea. These countries together account for about 6.66 percent of all outbound students. (c) Some European countries, such as Germany and France are also main senders of international students, accounting for 2.4 and 1.8 percent respectively.

Table 1 Inbound and outbound students of the top 10 countries (2015)

\begin{tabular}{|c|c|c|c|}
\hline Destination & Inbound & Origin & Outbound \\
\hline United States & 907251 & China & 819524 \\
\hline United Kingdom & 430687 & India & 256636 \\
\hline China & 397635 & Republic of Korea & 107762 \\
\hline Australia & 294438 & Germany & 117104 \\
\hline France & 239409 & Nigeria & 92476 \\
\hline Germany & 228756 & France & 86690 \\
\hline Russian Federation & 226431 & Saudi Arabia & 86242 \\
\hline Canada & 171603 & Kazakhstan & 78260 \\
\hline Japan & 131980 & United States & 70553 \\
\hline Malaysia & 111443 & Viet Nam & 68046 \\
\hline$\%$ of Total & $65.57 \%$ & $\%$ of Total & $37.24 \%$ \\
\hline
\end{tabular}

Source: The data are mainly derived from UIS statistics by the authors, and the inbound data of international students in China are from China Ministry of Education.

\subsection{International students in higher education in China}

Much of the mobility of international students has been one direction in recent history: from the South to the North. However, China has somewhat changed this history. In 2000, only 0.05 million international students studied in China, which merely accounts for about 3.09 percent of the world total. By the end of 2015, the share has 
increased to 8.63 percent and more than 0.397 million in total. Among them, 184,799 came to receive academic education, accounting for 46.47 percent of the total. Moreover, postgraduate students and doctoral students account for about $21.2 \%$ and $7.8 \%$ respectively. Columns (1) and (2) in Table 2 list the inbound students from the top 10 countries. We find that, (a) although the source covers 203 countries and regions, the top 10 origin countries contribute more than half of all international students in 2015 Most of the top origin countries are neighbors or countries with close economic exchanges, such as the U.S. and France. (b) The Republic of Korea remains the most important source. In 2015 , it accounts for $16.77 \%$ of the total, which is more than three times the share of the U.S. (c) The top 10 source countries remain unchanged, but the countries along the "belt and road initiative" (BRI) become the new growth point for international students in China. In 2015, six of the top 10 origin countries are the partners of BRI, namely Thailand, India, Russia, Pakistan, Kazakhstan and Indonesia.

Although China has become the third largest destination country, its international education level is relatively low. According to Education at a Glance 2015 published by the $\mathrm{OECD},{ }^{4}$ the proportion of international students at school is respectively 17.97 and 3.87 percent in Australia and the U.S., compared to only 0.46 percent in China. These figures indicate a huge room for China to attract more international students.

On the other hand, for outbound students from China, the total number stands at 0.813 million in 2015. By the end of 2015, Chinese students account for more than 30 percent of the total international students in the U.S. and Canada, and about 27.3 percent in Australia. The percentage reaches as high as 55.9 and 62 percent, respectively in South Korea and Japan. In some European countries, China is also the most important source of their international students, accounting for about 10 percent, such as in the U.K., Russia and Sweden. Columns (3) and (4) in Table 2 list outbound students to the top 10 countries from China. We find that, (a) Chinese students are highly concentrated in the top 10 destinations that have attracted more than four-fifths of China's outbound students in 2015. (b) English-speaking countries are their most popular destinations,

\footnotetext{
${ }^{4}$ OECD (2015), Education at a Glance 2015, http://www.oecd.org/education/education-at-a-glance-2015.htm
} 
perhaps for their high-quality education and better opportunities with the English language after graduation. (c) The U.S. is the top destination for Chinese students. In 2015, it receives more than twice as many Chinese students than the other three big English-speaking countries, the U.K., Canada and Australia. (d) The deficit between the outbound and inbound students has increasingly become a challenge. The net outflow of Chinese students has increased from 0.102 million in 2000 to 0.422 million in 2015, which has more than quadrupled in the past 15 years.

Table 2 Inbound and outbound students in the top 10 countries (China, 2015)

\begin{tabular}{|c|c|c|c|}
\hline Origin & Inbound & Destination & Outbound \\
\hline Republic of Korea & 66672 & United States & 291063 \\
\hline United States & 21978 & Australia & 97387 \\
\hline Thailand & 19976 & United Kingdom & 91518 \\
\hline India & 16694 & Japan & 79175 \\
\hline Russia & 16197 & Canada & 54660 \\
\hline Pakistan & 15654 & Republic of Korea & 34513 \\
\hline Japan & 14085 & France & 25297 \\
\hline Kazakhstan & 13198 & Germany & 23616 \\
\hline Indonesia & 12694 & New Zealand & 15009 \\
\hline France & 10436 & Italy & 12581 \\
\hline$\%$ of Total & $52.20 \%$ & \% of Total & $88.44 \%$ \\
\hline
\end{tabular}

Source: The outbound data are derived from UIS statistics by the authors, and the inbound data are from China Ministry of Education.

\section{Econometric model and data}

\subsection{Related definitions}

(1) International Students. According to the definition of UNESCO Institute for Statistics (UIS), international students are students who have crossed a national or territorial border for the purpose of education and are now enrolled outside their country of origin. At the $29^{\text {th }}$ General Conference in November, 1997, UNESCO endorsed the "International Standard Classification of Education (ISCED)". It divides education into six levels: Level 0--Pre-primary education, Level 1--primary education or the first stage of basic education, Level 2--lower secondary or the second stage of basic education, Level 3-(upper) secondary education, Level 4-post-secondary non-tertiary education, Level 5-first stage of tertiary education (not leading directly to an advanced research 
qualification) and Level 6-second stage of tertiary education (leading to an advanced research qualification). The higher education discussed in this paper includes Levels 5 and 6, specifically, short-cycle tertiary education, Bachelor's or equivalent level, Master's or equivalent level, Doctoral or equivalent level. ${ }^{5}$

(2) Cultural Products and Trade in Cultural Goods. According to UNESCO, cultural goods are defined as consumer goods that convey ideas, symbols, and ways of life. ${ }^{6}$ In 2005, UNESCO updated the classification and statistical description of trade in cultural products, and divided cultural goods into core products and related products. In this paper, we use the trade data of core cultural products only. It includes cultural heritage (antiques), printed matter (books, newspapers and periodicals, etc.), music and the performing arts (recording media), visual arts (painting, etc.) and audio and audiovisual media (photography, cinema and news media), given data availability. At the three- and four-digit SITC Rev.3 level, cultural goods are composed of 8961, 8962, 8963, 8964, 8965, 8966, 8921, 8922, 8924, 8986, 8987, 8826, 883, and 89431.

\subsection{Econometric model and data}

Based on the gravity model, we initially choose independent variables considering three aspects: cultural factors, economic factors and educational factors, ${ }^{7}$ and set up the following econometric model:

$$
\ln m o b s t u_{i j t}=\alpha_{0}+\beta X_{i j t}+\delta C P_{i j t}+\lambda_{i}+\lambda_{j}+\lambda_{t}+\varepsilon_{i j t}
$$

In (1), mobstu $u_{i j t}$ indicates the number of international students flowing from country $i$ to country $j$; $\mathrm{X}_{i j t}$ is a set of controls, including five variables: (1) the ratio of GDP per capita of the host country to the home country (gdpperratio $i j t)$; (2) the purchasing power parity of the host country $\left({ } p p_{i j t}\right)$; (3) the share of the host country's higher education expenditure in its GDP $\left(\operatorname{expeg}_{j} p_{j t}\right)$; (4) the student-teacher ratio of the host country's higher education (stutea); (5) the population weighted geographic

\footnotetext{
${ }^{5}$ For more information, see: http://www.unesco.org/education/information/nfsunesco/doc/isced_1997.htm.

${ }^{6}$ UNESCO Institute for Statistics (2005): International flows of selected cultural goods and services, 1994 -2003. http://www.uis.unesco.org/Library/Documents/culture05_en.pdf.

7 We exclude political factors that have been extensively studied in the literature (see for instance Caruso and Wit, 2015, who find that the crime rate in the destination countries is insignificant in attracting international students).
} 
distance (distance $i j t) ; \mathrm{CP}_{i j t}$ is the set of cultural proximity factors; $\lambda_{i}$ and $\lambda j$ are the country fixed effects, $\lambda_{t}$ represents the year fixed effects, and $\varepsilon_{i j t}$ is the error term.

In addition, we propose to add the following four indicators. The first two measures the time-variant cultural factors, while the latter two are time-invariant:

(i) Exports of cultural goods (lncultrade $i j t)$. We use the export value of cultural products from country $i$ to country $j$ in year $t$ to represent the cultural output of the students' destination country. Cultural products contain the customs and traditions, values and beliefs of a country. The trade in cultural products is associated with the exchange of culture and information between countries (see Disdier et al., 2010).

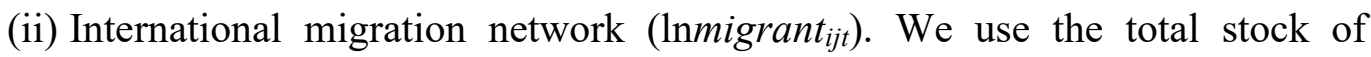
migrants from country $i$ to country $j$ in year $t$ to measure the scale of international migration networks. Immigrants bring the characteristic traditions of their religion and culture with them, and promote cultural exchanges between countries (see Scheffler, 2007). They can also play a major role for their followers as a bridge to inclusion in a new cultural environment (Fone and Alba, 2008). It is more likely that international students will choose a country with more national migrants as their destination. While the data of bilateral migrant stocks is on the bases of every five-years, we supplement the gap between two intervals by using the data in the initial year.

(iii) Common official language (language $e_{i j}$. Following Helpman, Melitz and Rubinstein (2008) and Beine et al. (2014), we use a dummy variable to measure linguistic proximity. Language is the most important part of a culture. In the broadest sense, language is also the symbolic representation of a people, since it comprises their historical and cultural backgrounds (Jiang, 2000; Brown, 1994). Students studying in countries with similar languages are easier to communicate, and these similarities ease the cultural shock and cultural conflicts in the host country.

(iv) Common religion ( religion $_{i j}$ ). A dummy variable is used to measure religious proximity. International students prefer to migrate to a destination country where their old religion can be practiced in a friendlier environment, and they face incentives to switch to a less costly religion (see Chiswick, 2014).

With the above incorporated, then Eq. (1) can be modified as: 


$$
\begin{aligned}
\ln \text { mobstu }_{i j t}= & \alpha_{0}+\beta X_{i j t}+\delta_{1} \text { lncultrade }_{i j t}+\delta_{2} \ln \text { migrant }_{i j t} \\
& +\delta_{3} \text { language }_{i j}+\delta_{4} \text { religion }_{i j}+\lambda_{i}+\lambda_{j}+\lambda_{t}+\varepsilon_{i j t}
\end{aligned}
$$

\subsection{Data specification}

The data comes mainly from the UN Comtrade (the United Nations Commodity Trade Database), UIS (UNESCO Data Research Center), OECD (Organization for Economic Co-operation and Development), IIE (Institute of International Education), CEPII (the French Centre d'Etudes Prospectives et d'Informations Internationales) database, the UN immigration database and other official websites. The bilateral data of international students in China is derived from China's Ministry of Education. The data on cultural goods trade are arranged by the 5-digit "Standard International Trade Classification (Third Edition)" (SITC Rev.3). Table 3 provides a description of the variables used in our analysis.

It should be noted that, in a model involving multiple countries, it is necessary to take into account the zero value of the dependent variable. That is, international students from a certain country may prefer to move to some countries but not others, and international students in a destination country may have come mainly from some certain origin countries. If we arbitrarily remove the zero values from our sample, it will result in a loss of useful information, leading to biased estimation (Eichengreen and Irwin, 1998). To resolve this problem, we follow the method in Liu and Qiu (2016), and add 1 to the dependent variable in the benchmark regression and then take logarithm. This transformation allows us to keep all observations. Later in the robustness checks, we also use another log-like transformation to test our results.

Table 3: Descriptive statistics by countries

\begin{tabular}{ccccccc}
\hline & \multicolumn{2}{c}{ Full Sample } & \multicolumn{2}{c}{ Developing Destinations } & \multicolumn{2}{c}{ Developed Destinations } \\
\cline { 2 - 6 } & Mean & Std. dev. & Mean & Std. dev. & Mean & Std. dev. \\
\hline gdpperratio & 8.9467 & 26.1645 & 4.2129 & 17.1500 & 18.4143 & 36.4837 \\
lndistance & 15.5188 & 0.8228 & 15.6400 & 0.7292 & 15.2764 & 0.9379 \\
ppp & 1.1907 & 1.2627 & 1.3506 & 1.5104 & 0.8709 & 0.2593 \\
expegdp & 4.5436 & 1.6950 & 4.1711 & 1.8099 & 5.2725 & 1.1325 \\
stutea & 15.8382 & 6.8558 & 18.3974 & 7.2590 & 11.3872 & 2.4295 \\
lncultrade & 6.4114 & 6.6391 & 4.7183 & 6.1515 & 9.7976 & 6.2734 \\
lnmigrant & 2.9653 & 3.7608 & 1.6208 & 3.0547 & 5.6542 & 3.5949 \\
\hline
\end{tabular}




\begin{tabular}{ccccccc}
\hline language & 0.0949 & 0.2931 & 0.1057 & 0.3075 & 0.0734 & 0.2608 \\
religion & 0.1398 & 0.2325 & 0.1268 & 0.2284 & 0.1658 & 0.2384 \\
\hline
\end{tabular}

\section{Empirical Analysis}

\subsection{Student flow in a global perspective}

We try to adopt a global perspective, by selecting 102 countries or regions as destination countries. Our empirical strategy is as follows: first, we analyze the four most basic explanatory variables as in Eq. (1) and obtain regression results; then we gradually add the cultural variables to be tested into the regressions following Eq. (2); and finally, we run regressions on all the variables.

As can be seen from Table 4, in both Model 3 and Model 4, the coefficients of cultural goods trade are positive and significant at the $1 \%$ level. It indicates that, from a global perspective, with the increase of one country's exports of cultural goods, its ability to attract international students also increases. To some extent, the exports of cultural products can be perceived as a kind of soft power. For instance, the international appeal of media culture has become the focal point of soft power in many policy discussions (Iwabuchi, 2015); Also, many governments encourage the private sector to produce and export commodified culture (Otmazgin, 2012).

Because cultural products contain customs and traditions, values and beliefs, international trade in cultural products is equivalent to the exchange of culture and information between countries. The more cultural products one country exports, the more attractive and valuable its culture is to other countries. Such exports can also induce more people to become in favor of the country's culture, values, customs, regime, etc., a good example of which is the so-called "American Dream".

In Table 4, the coefficients of immigrants (lnmigrant) are positive. The interpretation is that the more immigrants one country has, the stronger is its ability to attract international students. It should be clear that these migrants include all categories and in particular economic migrants, people coming under family reunification and previous students settling in the country where they receive education. These migrants 
are likely to provide assistance and information to students from their home countries and therefore decrease the migration costs. The presence of country nationals at a destination tends to act as a magnet for international students for several reasons. Immigrants from the source countries have various connections to their homelands, and immigration makes them feel closer to each other. The existence of an international migration network has a large positive pushing effect both physically and mentally. A large number of immigrants in a country indicates the country is open and tolerant, so that foreign immigrants are able to live peacefully there.

Table 4: Regression results of 102 countries and regions

\begin{tabular}{ccccc}
\hline & Model 1 & Model 2 & Model 3 & Model 4 \\
\hline lngdpper & $1.0090^{* * *}$ & 0.1809 & $0.6022^{* *}$ & 0.2012 \\
ppp & $(3.93)$ & $(0.65)$ & $(2.46)$ & $(0.72)$ \\
& 0.0011 & 0.0013 & 0.0009 & 0.0012 \\
expegdp & $(0.94)$ & $(1.49)$ & $(0.94)$ & $(1.40)$ \\
& 0.2188 & $0.3257^{* *}$ & $0.3250^{* *}$ & $0.3447^{* *}$ \\
stutea & $(1.13)$ & $(2.23)$ & $(2.00)$ & $(2.38)$ \\
& $-0.1024^{* *}$ & $-0.1350^{* *}$ & $-0.1110^{* *}$ & $-0.1318^{* *}$ \\
lncultrade & $(-2.10)$ & $(-2.55)$ & $(-2.44)$ & $(-2.55)$ \\
& & $0.5327^{* * *}$ & & $0.4111^{* * *}$ \\
lnmigrant & & $(4.87)$ & & $(2.68)$ \\
& & & $0.7307^{* * *}$ & 0.3022 \\
Constant & -2.2258 & $-4.7869^{* *}$ & $(3.87)$ & $(1.25)$ \\
& $(-0.95)$ & $(-2.00)$ & $-8.3274^{* * *}$ & $-6.7079^{* *}$ \\
\hline Observations & 1170 & 1169 & $(-2.90)$ & $(-2.27)$ \\
\hline $\mathrm{R}^{2}$ & 0.2562 & 0.3545 & 0.3282 & 1169 \\
\hline
\end{tabular}

Note: $* * *, * * *$ indicate that the variable is significant at the $10 \%, 5 \%$ and $1 \%$ levels, respectively. Robust $t$ Statistics are in parentheses. Standard errors are clustered by country. Time fixed effects are controlled in all regressions.

\subsection{Student flow between developing countries}

The asymmetry in economic conditions, education quality and social cultures is a typical characteristic between developing and developed countries. As a result, the incentives to study abroad are likely to vary across developing and developed origin countries (Abbott and Silles, 2016). According to UN classification, we divide 102 sample countries into developing (36 countries) and developed countries (66 countries). 
In subsequent analysis, we also add three bilateral variables: geographic distance (distance), common official language (language), and common religion (religion), following Eq. (2).

We start by analyzing the link between cultural factors and cross-border mobility between developing countries. The empirical results are shown in Table 5. In Models 2 and 6 , the coefficients of cultural trade are positive, and are significant at the $1 \%$ level. In Models 3 and 6, the coefficients of immigrants are significantly positive. However, in Model 6, the common official language shows a significant negative effect on the introduction of international students, which is contrary to our expectation. In addition, we find that educational factors in the host country are more important than economic factors when students flow between developing countries. To be specific, the coefficients of education expenditure on education as a percentage of GDP (expegdp) and student-teacher ratio (stutea) are larger and more significant than those of relative GDP per capita (gdpperratio). It can be interpreted that better education quality and more scholarships are preferred by international students. In addition, the coefficient of geographic distance (lndistance) is negative and statistically significant at $1 \%$ level in all models, indicating that international students from developing countries prefer to study in nearby developing countries.

Overall, trade in cultural products and migrant networks are the two main cultural determinants of international students who come from developing countries and study in other developing countries. They tend to choose destinations near their homelands that speak different languages. Also, the host countries' financial expenditure and human resource investment on higher education cast important influences on the destination choice of international students from developing countries.

Table 5: Student flow between developing countries

\begin{tabular}{ccccccc}
\hline & Model 1 & Model 2 & Model 3 & Model 4 & Model 5 & Model 6 \\
\hline gdpperratio & 0.0007 & -0.00002 & 0.0002 & 0.0007 & 0.0007 & -0.00002 \\
& $(1.15)$ & $(-0.05)$ & $(0.35)$ & $(1.20)$ & $(1.13)$ & $(-0.05)$ \\
Indistance & $-0.5899^{* * *}$ & $-0.3948^{* * *}$ & $-0.2955^{* * *}$ & $-0.5959^{* * *}$ & $-0.5830^{* * *}$ & $-0.2967^{* * *}$ \\
& $(-14.23)$ & $(-11.21)$ & $(-8.28)$ & $(-13.91)$ & $(-13.45)$ & $(-8.67)$ \\
ppp & -0.0283 & 0.0012 & -0.0203 & -0.0295 & -0.0280 & -0.0051
\end{tabular}




\begin{tabular}{|c|c|c|c|c|c|c|}
\hline & $(-1.55)$ & $(0.08)$ & $(-1.21)$ & $(-1.61)$ & $(-1.53)$ & $(-0.35)$ \\
\hline \multirow[t]{2}{*}{ expegdp } & $0.0756^{* * *}$ & $0.0846^{* * *}$ & $0.0735^{* * *}$ & $0.0759^{* * *}$ & $0.0757^{* * *}$ & $0.0841^{* * *}$ \\
\hline & $(7.23)$ & (8.69) & $(7.01)$ & $(7.27)$ & $(7.23)$ & $(8.51)$ \\
\hline \multirow[t]{2}{*}{ stutea } & $-0.0118^{* * *}$ & $-0.0122^{* * *}$ & $-0.0107^{* * *}$ & $-0.0116^{* * *}$ & $-0.0120^{* * *}$ & $-0.0100^{* * *}$ \\
\hline & $(-5.36)$ & $(-6.52)$ & $(-5.25)$ & $(-5.25)$ & $(-5.40)$ & $(-5.34)$ \\
\hline \multirow[t]{2}{*}{ lncultrade } & & $0.1229^{* * *}$ & & & & $0.1093^{* * *}$ \\
\hline & & $(23.07)$ & & & & (19.99) \\
\hline \multirow[t]{2}{*}{$\ln$ migrant } & & & $0.1750^{* * *}$ & & & $0.0960^{* * *}$ \\
\hline & & & (13.37) & & & $(7.70)$ \\
\hline \multirow[t]{2}{*}{ language } & & & & -0.0517 & & $-0.3029^{* * *}$ \\
\hline & & & & $(-0.66)$ & & $(-4.18)$ \\
\hline \multirow[t]{2}{*}{ religion } & & & & & 0.0822 & -0.0823 \\
\hline & & & & & $(0.70)$ & $(-0.82)$ \\
\hline \multirow[t]{2}{*}{ Constant } & $9.1721^{* * *}$ & $5.7560^{* * *}$ & $4.4171^{* * *}$ & $9.2697^{* * *}$ & $9.0475^{* * *}$ & $4.2232^{* * *}$ \\
\hline & (13.86) & $(10.20)$ & $(7.76)$ & $(13.51)$ & (12.93) & $(7.65)$ \\
\hline Observations & 49647 & 49647 & 49647 & 49647 & 49647 & 49647 \\
\hline $\mathrm{R}^{2}$ & 0.1332 & 0.3087 & 0.2042 & 0.1333 & 0.1333 & 0.3286 \\
\hline
\end{tabular}

Note: ${ }^{*}{ }^{* *}, * * *$ indicate that the variable is significant at the $10 \%, 5 \%$ and $1 \%$ levels, respectively. Robust $t$ Statistics are in parentheses. Standard errors are clustered by country pairs. Time fixed effects and country fixed effects are controlled in all regressions. Unless otherwise explained, the following tables use the same notation.

\subsection{Student flow from a developing country to a developed country}

We next explore the impacts of cultural determinants on international students flowing from developing origins to developed destinations. The empirical results are reported in Table 6 .

In Models 2 and 6, the bilateral cultural trade, i.e., exports from developed countries to developing countries, shows a positive effect on international student mobility at the $1 \%$ level. However, in Models 4 and 6, the coefficients of common religion are positive, but merely statistically significant at the $1 \%$ level in Model 6 , indicating that international students from developing countries tend to choose developed countries which share a common religion as destinations.

In Models 3 and 6, migration networks have a very significant effect as a powerful push factor for international student mobility. For many young people, studying abroad is part of their life experience. In Pakistan, Thailand and Vietnam, studying abroad is considered as one way to promote the family's social status; In the Philippines, West Africa, South Africa and other regions, a large number of students have studied abroad; 
In Nigeria, $40 \%$ of college students have aspirations to study overseas to gain social status (UNDP, 2009). ${ }^{8}$ These countries have established cultures of international mobility, and the presence of international migration networks leads to the growth of such cultures and overall normalization of the mobility process.

In Models 5 and 6, the coefficients of a common official language are statistically positive at $1 \%$ level, since students can more easily adapt to the local environment when they study in countries and regions that share a common language. For example, language similarity drives Latin-American students to choose Spain as their destination. $15 \%$ of the international students in Spain come from Latin America, while only $12 \%$ in the USA come from those countries (D' Costa, 2006), even though the U.S. is much closer physically. Notice the interesting contrast: in terms of language, international students from developing countries tend to choose developing countries that are very different, but they choose developed countries that are similar.

In addition, when students from developing countries flow to developed countries, they are simultaneously affected by the economic and educational factors. Our results show that all economic and educational variables are significant in almost all models. On the one hand, students tend to choose countries with a relatively lower level of economic growth (lower living costs), as can be observed from the significantly negative coefficients of the gdpperratio variable in all models; On the other hand, international students from developing countries prefer to choose developed countries with a lower proportion of education expenditures and a higher student-teacher ratio, which may be easier for them to apply to. For example, the New Zealand National College used to be officially accredited and recommended by the New Zealand Qualifications Authority. These official qualifications together with low entry barriers encourage many Chinese students to study in this college. ${ }^{9}$ Besides, the coefficient of geographic distance (lndistance) is positive and statistically significant at $1 \%$ level in Model 6, indicating that international students from developing countries prefer to study in remote developed countries.

\footnotetext{
${ }^{8}$ UNDP: Human development report 2009, www.hdr.undp.org.

9 Zaobao, https://www.zaobao.com/realtime/china/story20180223-837439, February 23, 2018.
} 
In sum, the exports of cultural products from developed countries to developing countries and the migration networks between countries are significant determinants of developing country students, when choosing developed countries as destinations. Students from developing countries tend to choose developed destinations that share a common language. However, they tend to choose those developed countries with a lower share of financial expenditure and a higher student-teacher ratio.

Table 6: Results of student flow from a developing to a developed country

\begin{tabular}{|c|c|c|c|c|c|c|}
\hline & Model 1 & Model 2 & Model 3 & Model 4 & Model 5 & Model 6 \\
\hline \multirow[t]{2}{*}{ gdpperratio } & $0.0153^{* * *}$ & $0.0025^{* * *}$ & 0.0015 & $0.0130^{* * *}$ & $0.0154^{* * *}$ & $-0.0017^{*}$ \\
\hline & (11.90) & (2.84) & $(1.32)$ & (10.74) & (12.02) & $(-1.88)$ \\
\hline \multirow[t]{2}{*}{ Indistance } & $-0.5060^{* * *}$ & -0.0500 & $0.3761^{* * *}$ & $-0.5324^{* * *}$ & $-0.4786^{* * *}$ & $0.3265^{* * *}$ \\
\hline & $(-4.70)$ & $(-0.56)$ & $(4.05)$ & $(-5.02)$ & $(-4.41)$ & $(3.76)$ \\
\hline \multirow[t]{2}{*}{$p p p$} & $-3.5970^{* * *}$ & $-1.4416^{* * *}$ & $-1.5858^{* * *}$ & $-3.3017^{* * *}$ & $-3.5793^{* * *}$ & $-0.9897^{* * *}$ \\
\hline & $(-21.58)$ & $(-10.43)$ & $(-10.35)$ & $(-20.88)$ & $(-21.42)$ & $(-7.63)$ \\
\hline \multirow[t]{2}{*}{$\operatorname{expegdp}$} & $-0.1771^{* * *}$ & $0.0438^{* *}$ & $-0.1417^{* * *}$ & $-0.1771^{* * *}$ & $-0.1720^{* * *}$ & $-0.0438^{* *}$ \\
\hline & $(-7.02)$ & $(2.03)$ & $(-5.58)$ & $(-7.08)$ & $(-6.80)$ & $(-2.05)$ \\
\hline \multirow[t]{2}{*}{ stutea } & $0.1401^{* * *}$ & $0.0694^{* * *}$ & $0.0576^{* * *}$ & $0.1057^{* * *}$ & $0.1406^{* * *}$ & $0.0311^{* * *}$ \\
\hline & $(8.48)$ & $(5.30)$ & $(4.50)$ & $(6.85)$ & $(8.46)$ & (2.65) \\
\hline \multirow[t]{2}{*}{ lncultrade } & & $0.2138^{* * *}$ & & & & $0.1041^{* * *}$ \\
\hline & & (33.73) & & & & (17.16) \\
\hline \multirow[t]{2}{*}{ lnmigrant } & & & $0.4226^{* * *}$ & & & $0.2964^{* * *}$ \\
\hline & & & (31.68) & & & (20.17) \\
\hline \multirow[t]{2}{*}{ language } & & & & $2.9037^{* * *}$ & & $1.4184^{* * *}$ \\
\hline & & & & (12.39) & & $(9.69)$ \\
\hline \multirow[t]{2}{*}{ religion } & & & & & $0.8909^{* * *}$ & 0.1582 \\
\hline & & & & & $(3.54)$ & $(1.12)$ \\
\hline \multirow[t]{2}{*}{ Constant } & $11.1242^{* * *}$ & 0.5660 & $-4.5670^{* * *}$ & $11.4943^{* * *}$ & $10.3175^{* * *}$ & $-4.9832^{* * *}$ \\
\hline & $(6.25)$ & $(0.38)$ & $(-2.94)$ & $(6.53)$ & $(5.71)$ & $(-3.40)$ \\
\hline Observations & 29172 & 29172 & 29172 & 29172 & 29172 & 29172 \\
\hline $\mathrm{R}^{2}$ & 0.3397 & 0.5088 & 0.5766 & 0.4068 & 0.3428 & 0.6216 \\
\hline
\end{tabular}

\subsection{Student flows between developed countries}

In this section, we turn to investigate the role of cultural factors in determining the student mobility between developed countries. Table 7 presents the empirical results.

In Models 2 and 6, the coefficients of bilateral cultural trade (lncultrade) are positive and statistically significant, showing that the cultural output among developed countries has a positive effect on attracting their counterparts' students. In Models 3 
and 6 , the coefficients of the immigrant stock (lnmigrant) are significantly positive, indicating that migration networks are important for student mobility between developed nations. In Models 4 and 6, the coefficients of a common official language (language) are significantly positive, implying that international students from developed countries tend to study in other developed countries that share a common language. In Models 5 and 6, the coefficients of common religion (religion) are significantly positive, indicating that international students from developed countries tend to study in other developed countries that share a common religious belief.

In addition, the economic and educational factors are important determinants of developed country students choosing developed countries as destinations. However, in contrast to the flows from a developing to a developed country, the coefficients of relative GDP per capita (gdpperratio) in all six models are significantly positive, indicating that international students from developed countries tend to choose those developed countries with a higher income level. Also, the education expenditure $(\operatorname{expegdp})$ in the host countries also exerts a significant effect on the location choice of international students. Further, the coefficient of geographic distance (lndistance) is positive and statistically significant at $1 \%$ level in Model 6, indicating that international students from developed countries prefer to study in other remote developed countries.

In general, the exports of cultural goods and international migration networks are significant factors affecting the choices of developed country students to study in other developed countries. They tend to choose developed countries that share a common language and a common religion belief.

Table 7: Student flow between developed countries

\begin{tabular}{ccccccc}
\hline & Model 1 & Model 2 & Model 3 & Model 4 & Model 5 & Model 6 \\
\hline gdpperratio & $0.5390^{* * *}$ & $0.2395^{* * *}$ & $0.2491^{* * *}$ & $0.5362^{* * *}$ & $0.5417^{* * *}$ & $0.1600^{* * *}$ \\
& $(9.87)$ & $(7.00)$ & $(6.52)$ & $(9.81)$ & $(9.86)$ & $(5.41)$ \\
Indistance & $-0.6284^{* * *}$ & -0.0345 & -0.0003 & $-0.5918^{* * *}$ & $-0.5451^{* * *}$ & $0.1974^{* * *}$ \\
& $(-8.72)$ & $(-0.59)$ & $(-0.00)$ & $(-8.48)$ & $(-7.20)$ & $(3.50)$ \\
ppp & $-3.6516^{* * *}$ & $-0.8481^{* * *}$ & $-1.1959^{* * *}$ & $-3.3410^{* * *}$ & $-3.5504^{* * *}$ & -0.1293 \\
& $(-12.67)$ & $(-3.54)$ & $(-4.66)$ & $(-11.61)$ & $(-12.15)$ & $(-0.59)$ \\
expegdp & -0.0113 & $0.3229^{* * *}$ & $0.0956^{* *}$ & -0.0202 & -0.0218 & $0.2563^{* * *}$ \\
& $(-0.29)$ & $(9.53)$ & $(2.47)$ & $(-0.51)$ & $(-0.58)$ & $(7.76)$
\end{tabular}




\begin{tabular}{ccccccc} 
stutea & $0.1144^{* * *}$ & $0.0739^{* * *}$ & 0.0291 & $0.0885^{* * *}$ & $0.1116^{* * *}$ & 0.0204 \\
& $(4.35)$ & $(3.47)$ & $(1.35)$ & $(3.47)$ & $(4.19)$ & $(1.00)$ \\
$\ln ($ cultrade $)$ & & $0.3390^{* * *}$ & & & & $0.2038^{* * *}$ \\
& & $(23.45)$ & & & & $(16.01)$ \\
$\ln ($ migrant $)$ & & & $0.4926^{* * *}$ & & & $0.3376^{* * *}$ \\
& & & $(21.24)$ & & & $(14.47)$ \\
language & & & & $1.9885^{* * *}$ & & $0.8030^{* * *}$ \\
& & & & $(6.41)$ & & $(3.33)$ \\
religion & & & & & $0.9655^{* * *}$ & $0.2730^{*}$ \\
& & & & & $(4.16)$ & $(1.68)$ \\
Constant & $14.0230^{* * *}$ & $-3.5785^{* * *}$ & -1.2212 & $13.2243^{* * *}$ & $12.4920^{* * *}$ & $-7.7608^{* * *}$ \\
& $(10.61)$ & $(-3.09)$ & $(-1.12)$ & $(10.33)$ & $(8.97)$ & $(-7.12)$ \\
\hline Observations & 14157 & 14157 & 14157 & 14157 & 14157 & 14157 \\
$\mathrm{R}^{2}$ & 0.3030 & 0.4694 & 0.4999 & 0.3279 & 0.3104 & 0.5502 \\
\hline
\end{tabular}

\subsection{Student flow from a developed to a developing country}

We finally investigate how international students from developed countries to developing countries are affected by bilateral cultural factors, as listed in Table 8 . The regression results of Models 2, 3 and 6 show that the coefficients of the exports of cultural goods (lncultrade) and the immigration stock (lnmigrant) are all positive and statistically significant. However, in Models 4 to 6 , the coefficients of the common language (language) and common religion (religion) are negative and statistically significant, implying that students from developed countries tend to choose developing countries that speak different languages and have differentiated religious beliefs as destinations, especially for non-degree seeking students.

Table 8: Student flow from a developed to a developing country

\begin{tabular}{ccccccc}
\hline & Model 1 & Model 2 & Model 3 & Model 4 & Model 5 & Model 6 \\
\hline gdpperratio & 0.0161 & 0.0128 & 0.0040 & 0.0210 & 0.0147 & 0.0093 \\
& $(0.88)$ & $(0.96)$ & $(0.26)$ & $(1.12)$ & $(0.81)$ & $(0.70)$ \\
Indistance & $-0.2077^{* * *}$ & $-0.2016^{* * *}$ & $-0.1533^{* * *}$ & $-0.2127^{* * *}$ & $-0.1705^{* * *}$ & $-0.1098^{* *}$ \\
& $(-3.57)$ & $(-4.03)$ & $(-3.14)$ & $(-3.66)$ & $(-2.62)$ & $(-2.27)$ \\
ppp & $-0.0366^{* *}$ & -0.0205 & $-0.0493^{* * *}$ & $-0.0394^{* *}$ & $-0.0379^{* *}$ & $-0.0371^{* * *}$ \\
& $(-2.27)$ & $(-1.60)$ & $(-3.41)$ & $(-2.43)$ & $(-2.32)$ & $(-3.04)$ \\
expegdp & -0.0104 & 0.0008 & -0.0115 & -0.0097 & -0.0073 & 0.0043 \\
& $(-1.07)$ & $(0.10)$ & $(-1.21)$ & $(-1.00)$ & $(-0.78)$ & $(0.52)$ \\
stutea & $-0.0074^{* * *}$ & -0.0020 & -0.0045 & $-0.0060^{* *}$ & $-0.0066^{* *}$ & 0.0026 \\
& $(-2.59)$ & $(-0.88)$ & $(-1.60)$ & $(-2.13)$ & $(-2.34)$ & $(1.17)$
\end{tabular}




\begin{tabular}{|c|c|c|c|c|c|c|}
\hline \multirow[t]{2}{*}{ lncultrade } & & $0.1008^{* * *}$ & & & & $0.0864^{* * *}$ \\
\hline & & $(17.29)$ & & & & $(14.06)$ \\
\hline \multirow[t]{2}{*}{ lnmigrant } & & & $0.1275^{* * *}$ & & & $0.0874^{* * *}$ \\
\hline & & & (9.45) & & & $(6.31)$ \\
\hline \multirow[t]{2}{*}{ language } & & & & $-0.3930^{* * *}$ & & $-0.5156^{* * *}$ \\
\hline & & & & $(-3.57)$ & & $(-5.63)$ \\
\hline \multirow[t]{2}{*}{ religion } & & & & & $-0.4024^{* * *}$ & $-0.6687^{* * *}$ \\
\hline & & & & & $(-3.27)$ & $(-6.65)$ \\
\hline \multirow[t]{2}{*}{ Constant } & $4.2870^{* * *}$ & $3.1566^{* * *}$ & $2.9650^{* * *}$ & $4.4241^{* * *}$ & $3.6823^{* * *}$ & $1.5862^{* *}$ \\
\hline & $(4.42)$ & (3.87) & (3.78) & $(4.56)$ & (3.44) & (2.04) \\
\hline Observations & 25194 & 25194 & 25194 & 25194 & 25194 & 25194 \\
\hline $\mathrm{R}^{2}$ & 0.0783 & 0.2557 & 0.1412 & 0.0826 & 0.0816 & 0.2847 \\
\hline
\end{tabular}

\subsection{Further analysis related to China}

\subsubsection{Cultural factors and inbound students in China}

So far we have looked at global samples. In this subsection, we examine the case related to China. A survey in Beijing found that the interest in Chinese culture is the most important determinant of international students studying in China (Liu et al., 2013). To be specific, about $93 \%$ international students hold that they choose to study in China due to their interest in traditional Chinese culture and the desire to learn more about China. ${ }^{10}$ The survey results confirm our conclusion that cultural factors significantly affect the destination choice of international students, and it is especially true for developing destinations.

Among various cultural factors, common language plays an obvious role in determining international students to developing destinations which is consistent with our empirical findings. With the rise of China's economic scale and international influence, a "Chinese fever" has swept the world. In this context, the study of Chinese language has become a necessary skill for personal development and business cooperation for many countries. The employment prospects of international students who are proficient in Chinese are more promising, which in turn encourages more international students to come. In 2015, about 45.6 percent international students majored in the Chinese language, which is nearly four times that in western medicine,

\footnotetext{
${ }^{10}$ Details of the survey data can be found in Table 1 of Liu et al. (2013).
} 
the second largest major. More detailed statistics show that about 85.82 percent students majored in the Chinese language are non-degree seeking, indicating their urgent need to learn the language. ${ }^{11}$

Also, Wei et al. (2018) find that cultural factors, such as linguistic difference and migration networks have significant effect on attracting international students to China. Further comparison reveals that the effect is stronger for students from developed countries than from developing countries. Qu et al. (2016) show that the improvement of cultural acceptance, measured as cultural products export to the origin countries, plays an important role in promoting the scale of international students in China.

\subsubsection{Cultural factors and outbound students from China}

As for outbound students from China, several surveys confirm our empirical conclusions derived from the global perspective in the previous sections. To be specific, a survey conducted by Mycos, China's first professional higher education management and consulting company, shows that about 27.1 and 19 percent of Chinese students studying in Europe and Oceania consider learning different cultures as the primary reason for their destination choice in 2015. In contrast, only 13.8 percent of Chinese students in other Asian countries regard learning cultures as the primary reason for their destination choice. ${ }^{12}$ This comparison shows that the influence of cultural factors on Chinese outbound students is smaller in developing countries than in developed countries, which is also consistent with our empirical results.

Another interesting finding is that social networks have an underestimated influence on the destination choice of Chinese outbound students. Overall, about 13.9 percent of interviewees believed that social network, as measured by the recommendation from friends, relatives, teachers and alumni, was the primary information channel, and it has become the third largest information source for Chinese students in $2015 .^{13}$ However, the impacts of social networks vary among destinations.

\footnotetext{
11 The data are derived from China Ministry of Education and calculated by the authors.

12 Details of the survey data can be found on p. 51 (Table 13), Annual Report on the Development of Chinese Students Studying Abroad (2016).

${ }_{13}$ Details of the survey data can be found on p. 49 (Table 10), Annual Report on the Development of Chinese Students Studying Abroad (2016).
} 
It has exerted the largest impact on Chinese students studying in neighboring Asian countries, while the impact is relatively weaker in developed countries. Specifically, about $20.7 \%$ of Chinese students in Asian countries select social network as the primary information channel. In contrast, those who regard social network as the most important information channel account respectively 11.3, 11.2 and 10.2 percent of total Chinese students in Oceania, Europe and North America. ${ }^{14}$

\section{Robustness Checks}

\subsection{Lagged explanatory variables}

In order to avoid possible endogeneity caused by reverse causality, we now use lagged explanatory variables to check the robustness of our results. Note that two of the variables, common official language (language) and common religion (religion), are time invariant, and they are not affected by the international students. Here we adopt one-period and two-period lagged explanatory variables of bilateral cultural trade (lncultrade) and immigrant networks (lnmigrant). The regression results are reported in Table 9, confirming that our findings are robust. The results show that the export of cultural products is conducive to the increase of international students. Migrant networks are also beneficial for attracting students from the origin countries. However, the impact of time-invariant cultural determinants depends on the types of origin countries and destination countries. To be specific, the common official language significantly increases the international students to developed destinations. By contrast, international students prefer to choose developing destinations whose official language is different from their origin countries. The contrast comes from the fact that students studying in developed countries are more focused on degree courses or improving their living standards via future immigration, while in developing countries, they mainly aim at learning unique foreign languages and experiencing differentiated cultures.

Common religion is an important cultural determinant for students from developed countries, and it significantly increases the students from developed countries to study

\footnotetext{
${ }_{14}$ Details of the survey data can be found on p. 55 (Table 19), Annual Report on the Development of Chinese Students Studying Abroad (2016).
} 
in another developed destination. By contrast, international students from developed countries prefer to choose developing destinations whose religious belief is different from their origin countries. This result confirms our previous finding that international students studying in developing countries aim at experiencing differentiated cultures, such as foreign languages and religious beliefs.

Table 9: Robustness checks using lagged explanatory variables

\begin{tabular}{|c|c|c|c|c|c|c|c|c|c|c|}
\hline & \multicolumn{2}{|c|}{ global sample } & \multicolumn{2}{|c|}{$\begin{array}{c}\text { Between Developing } \\
\text { Countries }\end{array}$} & \multicolumn{2}{|c|}{$\begin{array}{c}\text { Developing to } \\
\text { Developed Countries }\end{array}$} & \multicolumn{2}{|c|}{$\begin{array}{c}\text { Between Developed } \\
\text { Countries }\end{array}$} & \multicolumn{2}{|c|}{$\begin{array}{c}\text { Developed to } \\
\text { Developing Countries }\end{array}$} \\
\hline & $\mathrm{t}-1$ & $\mathrm{t}-2$ & $\mathrm{t}-1$ & $\mathrm{t}-2$ & $\mathrm{t}-1$ & $\mathrm{t}-2$ & $\mathrm{t}-1$ & $\mathrm{t}-2$ & $\mathrm{t}-1$ & $t-2$ \\
\hline \multirow[t]{2}{*}{ lngdpper } & 0.1757 & 0.1768 & & & & & & & & \\
\hline & $(0.62)$ & $(0.62)$ & & & & & & & & \\
\hline \multirow[t]{2}{*}{ gdpperratio } & & & 0.0001 & 0.0002 & $-0.0020^{* *}$ & $-0.0023^{* *}$ & $0.1593^{* * *}$ & $0.1541^{* * *}$ & 0.0140 & 0.0177 \\
\hline & & & $(0.31)$ & $(0.37)$ & $(-2.18)$ & $(-2.47)$ & $(4.87)$ & $(4.31)$ & $(1.06)$ & $(1.21)$ \\
\hline \multirow[t]{2}{*}{ Indistance } & & & $-0.3009^{* * *}$ & $-0.2962^{* * *}$ & $0.3224^{* * *}$ & $0.3276^{* * *}$ & $0.1931^{* * *}$ & $0.2037^{* * *}$ & $-0.1115^{* *}$ & $-0.1073^{* *}$ \\
\hline & & & $(-8.73)$ & $(-8.58)$ & $(3.73)$ & $(3.81)$ & (3.43) & (3.59) & $(-2.31)$ & $(-2.23)$ \\
\hline \multirow[t]{2}{*}{ ppp } & 0.0012 & 0.0012 & -0.0021 & 0.0002 & $-1.0641^{* * *}$ & $-1.1183^{* * *}$ & -0.1219 & -0.0768 & $-0.0383^{* * *}$ & $-0.0397^{* * *}$ \\
\hline & $(1.42)$ & $(1.45)$ & $(-0.15)$ & $(0.01)$ & $(-7.23)$ & $(-6.85)$ & $(-0.55)$ & $(-0.34)$ & $(-3.13)$ & $(-3.25)$ \\
\hline \multirow[t]{2}{*}{ expegdp } & $0.3269^{* *}$ & $0.3052^{* *}$ & $0.0856^{* * *}$ & $0.0861^{* * *}$ & $-0.0415^{*}$ & $-0.0394^{*}$ & $0.2532^{* * *}$ & $0.2582^{* * *}$ & 0.0059 & 0.0073 \\
\hline & $(2.27)$ & $(2.11)$ & $(8.75)$ & $(8.89)$ & $(-1.92)$ & $(-1.81)$ & $(7.60)$ & (7.68) & $(0.72)$ & $(0.88)$ \\
\hline \multirow[t]{2}{*}{ stutea } & $-0.1421^{* * *}$ & $-0.1485^{* * *}$ & $-0.0104^{* * *}$ & $-0.0112^{* * *}$ & $0.0242^{* *}$ & 0.0155 & 0.0103 & -0.0001 & 0.0025 & 0.0020 \\
\hline & $(-2.77)$ & $(-2.83)$ & $(-5.44)$ & $(-5.72)$ & $(2.03)$ & $(1.28)$ & $(0.50)$ & $(-0.01)$ & (1.07) & $(0.84)$ \\
\hline \multirow[t]{2}{*}{ L.Incultrade } & $0.4178^{* * *}$ & & $0.1111^{* * *}$ & & $0.1042^{* * *}$ & & $0.2023^{* * *}$ & & $0.0868^{* * *}$ & \\
\hline & $(2.70)$ & & $(20.05)$ & & (17.05) & & $(15.71)$ & & (14.10) & \\
\hline \multirow[t]{2}{*}{ L.Inmigrant } & 0.3044 & & $0.0970^{* * *}$ & & $0.2965^{* * *}$ & & $0.3326^{* * *}$ & & $0.0884^{* * *}$ & \\
\hline & $(1.25)$ & & $(7.70)$ & & (20.07) & & (14.14) & & $(6.38)$ & \\
\hline \multirow[t]{2}{*}{ L2.Incultrade } & & $0.4125^{* *}$ & & $0.1132^{* * *}$ & & $0.1040^{* * *}$ & & $0.2040^{* * *}$ & & $0.0878^{* * *}$ \\
\hline & & $(2.64)$ & & (20.11) & & $(16.72)$ & & $(15.80)$ & & (14.19) \\
\hline \multirow[t]{2}{*}{ L2.lnmigrant } & & 0.3080 & & $0.0986^{* * *}$ & & $0.2978^{* * *}$ & & $0.3240^{* * *}$ & & $0.0903^{* * *}$ \\
\hline & & $(1.25)$ & & $(7.75)$ & & $(20.05)$ & & (13.78) & & $(6.47)$ \\
\hline \multirow[t]{2}{*}{ language } & & & $-0.3025^{* * *}$ & $-0.3083^{* * *}$ & $1.4161^{* * *}$ & $1.4196^{* * *}$ & $0.8184^{* * *}$ & $0.8527^{* * *}$ & $-0.5285^{* * *}$ & $-0.5518^{* * *}$ \\
\hline & & & $(-4.17)$ & $(-4.26)$ & (9.69) & $(9.64)$ & (3.38) & (3.49) & $(-5.72)$ & $(-5.86)$ \\
\hline \multirow[t]{2}{*}{ religion } & & & -0.0911 & -0.0752 & 0.1590 & 0.1698 & $0.2717^{*}$ & $0.2866^{*}$ & $-0.6750^{* * *}$ & $-0.6803^{* * *}$ \\
\hline & & & $(-0.90)$ & $(-0.73)$ & (1.13) & (1.19) & (1.67) & $(1.75)$ & $(-6.73)$ & $(-6.69)$ \\
\hline \multirow[t]{2}{*}{ Constant } & $-6.1664^{* *}$ & $-5.7044^{*}$ & $4.2789^{* * *}$ & $4.2601^{* * *}$ & $-4.7651^{* * *}$ & $-4.6142^{* * *}$ & $-7.2634^{* * *}$ & $-7.1632^{* * *}$ & $1.6240^{* *}$ & $1.6376^{* *}$ \\
\hline & $(-2.03)$ & $(-1.86)$ & $(7.67)$ & $(7.61)$ & $(-3.25)$ & $(-3.15)$ & $(-6.66)$ & $(-6.48)$ & $(2.10)$ & $(2.11)$ \\
\hline Observations & 1116 & 1056 & 47503 & 45024 & 27744 & 26180 & 13464 & 12705 & 24106 & 22848 \\
\hline $\mathrm{R}^{2}$ & 0.3680 & 0.3679 & 0.3309 & 0.3321 & 0.6226 & 0.6225 & 0.5446 & 0.5415 & 0.2862 & 0.2882 \\
\hline
\end{tabular}

\subsection{Alternative dependent variables}


To deal with zero values of the dependent variable, we add one to international student mobility in the baseline estimation before taking logarithm. In the robustness checks, we use another log-like transformation (see Liu and Qiu, 2016). It is calculated as, $\quad \operatorname{lnstudent}_{i j t}=\ln \left[\right.$ student $\left._{i j t}+\left(\text { student }_{i j t}{ }^{2}+1\right)^{1 / 2}\right]$. Table 10 reports the estimation results, again confirming our findings.

Table 10: Robustness checks using alternative dependent variables

\begin{tabular}{|c|c|c|c|c|c|}
\hline & global sample & $\begin{array}{c}\text { Between } \\
\text { Developing } \\
\text { Countries } \\
\end{array}$ & $\begin{array}{c}\text { Developing to } \\
\text { Developed } \\
\text { Countries }\end{array}$ & $\begin{array}{c}\text { Between } \\
\text { Developed } \\
\text { Countries }\end{array}$ & $\begin{array}{c}\text { Developed to } \\
\text { Developing } \\
\text { Countries } \\
\end{array}$ \\
\hline & (1) & (2) & (3) & (4) & (5) \\
\hline lngdpper & $\begin{array}{l}0.2124 \\
(0.71)\end{array}$ & & & & \\
\hline gdpperratio & & $\begin{array}{l}0.0001 \\
(0.16)\end{array}$ & $\begin{array}{c}-0.0014 \\
(-1.36)\end{array}$ & $\begin{array}{c}0.1775^{* * *} \\
(5.57)\end{array}$ & $\begin{array}{l}0.0164 \\
(1.05)\end{array}$ \\
\hline lndistance & & $\begin{array}{c}-0.3333^{* * *} \\
(-8.71)\end{array}$ & $\begin{array}{c}0.3644^{* * *} \\
(3.95)\end{array}$ & $\begin{array}{c}0.2418^{* * *} \\
(4.04)\end{array}$ & $\begin{array}{c}-0.1279^{* *} \\
(-2.38)\end{array}$ \\
\hline ppp & $\begin{array}{l}0.0013 \\
(1.39)\end{array}$ & $\begin{array}{c}-0.0006 \\
(-0.04)\end{array}$ & $\begin{array}{c}-1.1184^{* * *} \\
(-7.88)\end{array}$ & $\begin{array}{c}-0.0298 \\
(-0.13)\end{array}$ & $\begin{array}{c}-0.0377^{* * *} \\
(-2.71)\end{array}$ \\
\hline expegdp & $\begin{array}{c}0.3635^{* *} \\
(2.33)\end{array}$ & $\begin{array}{c}0.0979^{* * *} \\
(8.82)\end{array}$ & $\begin{array}{c}-0.0391^{*} \\
(-1.66)\end{array}$ & $\begin{array}{c}0.2927^{* * *} \\
(8.13)\end{array}$ & $\begin{array}{c}0.0079 \\
(0.82)\end{array}$ \\
\hline stutea & $\begin{array}{c}-0.1439^{* *} \\
(-2.60)\end{array}$ & $\begin{array}{c}-0.0118^{* * *} \\
(-5.54)\end{array}$ & $\begin{array}{c}0.0288^{* *} \\
(2.22)\end{array}$ & $\begin{array}{c}0.0124 \\
(0.56)\end{array}$ & $\begin{array}{l}0.0032 \\
(1.24)\end{array}$ \\
\hline lncultrade & $\begin{array}{c}0.4289^{* * *} \\
(2.64)\end{array}$ & $\begin{array}{c}0.1255^{* * *} \\
(20.59)\end{array}$ & $\begin{array}{c}0.1197^{* * *} \\
(17.81)\end{array}$ & $\begin{array}{c}0.2279^{* * *} \\
(16.42)\end{array}$ & $\begin{array}{c}0.1009^{* * *} \\
(14.79)\end{array}$ \\
\hline lnmigrant & $\begin{array}{c}0.3070 \\
(1.19)\end{array}$ & $\begin{array}{c}0.1059^{* * *} \\
(7.68)\end{array}$ & $\begin{array}{c}0.3234^{* * *} \\
(20.22)\end{array}$ & $\begin{array}{c}0.3544^{* * *} \\
(14.06)\end{array}$ & $\begin{array}{c}0.1010^{* * *} \\
(6.57)\end{array}$ \\
\hline language & & $\begin{array}{c}-0.3467^{* * *} \\
(-4.30)\end{array}$ & $\begin{array}{c}1.4992^{* * *} \\
(9.67)\end{array}$ & $\begin{array}{c}0.7839^{* * *} \\
(3.07)\end{array}$ & $\begin{array}{c}-0.6009^{* * *} \\
(-5.81)\end{array}$ \\
\hline religion & & $\begin{array}{c}-0.0824 \\
(-0.73)\end{array}$ & $\begin{array}{c}0.1610 \\
(1.03)\end{array}$ & $\begin{array}{c}0.3235^{*} \\
(1.86)\end{array}$ & $\begin{array}{c}-0.7759^{* * *} \\
(-6.78)\end{array}$ \\
\hline Constant & $\begin{array}{c}-6.6174^{* *} \\
(-2.09)\end{array}$ & $\begin{array}{c}4.7348^{* * *} \\
(7.68)\end{array}$ & $\begin{array}{c}-5.5079^{* * *} \\
(-3.55)\end{array}$ & $\begin{array}{c}-8.7713^{* * *} \\
(-7.57)\end{array}$ & $\begin{array}{c}1.8399^{* *} \\
(2.13)\end{array}$ \\
\hline Observations & 1169 & 49647 & 29172 & 14157 & 25194 \\
\hline $\mathrm{R}^{2}$ & 0.3510 & 0.3301 & 0.6230 & 0.5397 & 0.2913 \\
\hline
\end{tabular}

\subsection{Alternative measurement of cultural factors}

Hofstede (2010) proposes a framework of six cultural dimensions by which we can compare the cultural distance between two countries: power distance, uncertainty 
avoidance, individualism, masculinity, long-term orientation and indulgence. The index of cultural distance is calculated as,

$$
C D_{i j}=\sum_{c=1}^{n}\left(I_{c i}-I_{c j}\right)^{2} / n V_{c}
$$

In the above formula, $\mathrm{CD}_{i j}$ represents the cultural distance between countries $i$ and $j$; $\mathrm{I}_{c i}$ and $\mathrm{I}_{c j}$ show the index value of dimension $c$ in countries $i$ and $j ; n$ is the number of cultural dimensions; $\mathrm{V}_{c}$ is the variance of cultural dimension $c$.

However, the data of cultural distance are not available for all countries, especially for some developing countries. To avoid the bias of sample selection, we have not used this index in the baseline regression. Here we add it to our econometric model and conduct another robustness check. The results are shown in Table 11, basically confirming robustness, except for Model 6, where the common religion is positive but statistically insignificant, indicating that a common religion cannot significantly promote the mobility of international students between developed countries.

Table 11: Robustness checks using alternative cultural factor measurements

\begin{tabular}{|c|c|c|c|c|c|c|c|c|}
\hline & \multicolumn{2}{|c|}{$\begin{array}{c}\text { Between Developing } \\
\text { Countries }\end{array}$} & \multicolumn{2}{|c|}{$\begin{array}{c}\text { Developing to } \\
\text { Developed Countries }\end{array}$} & \multicolumn{2}{|c|}{$\begin{array}{c}\text { Between Developed } \\
\text { Countries }\end{array}$} & \multicolumn{2}{|c|}{$\begin{array}{c}\text { Developed to } \\
\text { Developing Countries }\end{array}$} \\
\hline & (1) & (2) & (3) & (4) & (5) & (6) & (7) & (8) \\
\hline \multirow[t]{2}{*}{ gdpperratio } & -0.0147 & -0.0115 & -0.0024 & -0.0001 & $0.1518^{* * *}$ & $0.1535^{* * *}$ & $-0.1668^{*}$ & $-0.1769^{* *}$ \\
\hline & $(-0.56)$ & $(-0.48)$ & $(-0.52)$ & $(-0.02)$ & $(5.01)$ & (5.03) & $(-1.87)$ & $(-1.97)$ \\
\hline \multirow[t]{2}{*}{ Indistance } & $-0.7167^{* * *}$ & $-0.8580^{* * *}$ & $0.3299^{* *}$ & 0.2331 & $0.2273^{* * *}$ & $0.2249^{* * *}$ & $-0.4406^{* * *}$ & $-0.3666^{* * *}$ \\
\hline & $(-6.85)$ & $(-7.55)$ & $(2.16)$ & (1.54) & (4.18) & (3.98) & $(-4.85)$ & $(-3.65)$ \\
\hline \multirow[t]{2}{*}{$p p p$} & -0.0707 & -0.0859 & $-1.1144^{* * *}$ & $-1.1672^{* * *}$ & -0.3064 & -0.2651 & $-0.1276^{* * *}$ & $-0.1375^{* * *}$ \\
\hline & $(-1.30)$ & $(-1.58)$ & $(-5.64)$ & $(-5.89)$ & $(-1.42)$ & $(-1.22)$ & $(-3.41)$ & $(-3.75)$ \\
\hline \multirow[t]{2}{*}{ expegdp } & $0.2013^{* * *}$ & $0.2219^{* * *}$ & -0.0311 & -0.0372 & $0.3222^{* * *}$ & $0.3139^{* * *}$ & $0.0927^{* * *}$ & $0.1019^{* * *}$ \\
\hline & $(4.90)$ & (5.55) & $(-0.76)$ & $(-0.92)$ & (9.52) & $(9.50)$ & (3.03) & $(3.35)$ \\
\hline \multirow[t]{2}{*}{ stutea } & $-0.0393^{* * *}$ & $-0.0255^{* *}$ & $0.0419^{*}$ & 0.0304 & 0.0177 & 0.0099 & $-0.0234^{* *}$ & $-0.0156^{*}$ \\
\hline & $(-3.22)$ & $(-2.10)$ & (1.93) & (1.44) & $(0.86)$ & $(0.48)$ & $(-2.52)$ & $(-1.70)$ \\
\hline \multirow[t]{2}{*}{ lncultrade } & $0.1273^{* * *}$ & $0.1266^{* * *}$ & $0.1137^{* * *}$ & $0.1148^{* * *}$ & $0.2179^{* * *}$ & $0.2179^{* * *}$ & $0.1349^{* * *}$ & $0.1252^{* * *}$ \\
\hline & (12.41) & (12.25) & (11.53) & (11.72) & (15.28) & (15.37) & (12.69) & (11.13) \\
\hline \multirow[t]{2}{*}{ lnmigrant } & $0.0593^{* *}$ & $0.0782^{* * *}$ & $0.3824^{* * *}$ & $0.3537^{* * *}$ & $0.3326^{* * *}$ & $0.3208^{* * *}$ & $0.0428^{* *}$ & $0.0699^{* * *}$ \\
\hline & $(2.27)$ & $(2.93)$ & (16.85) & (15.46) & (14.41) & (13.50) & $(2.10)$ & $(3.21)$ \\
\hline \multirow[t]{2}{*}{ language } & & $-0.8830^{* * *}$ & & $1.3803^{* * *}$ & & $0.7544^{* * *}$ & & $-0.6077^{* * *}$ \\
\hline & & $(-3.00)$ & & (5.55) & & (2.97) & & $(-2.88)$ \\
\hline \multirow[t]{2}{*}{ religion } & & $-0.5179^{* *}$ & & 0.2468 & & 0.0908 & & $-0.6799^{* * *}$ \\
\hline & & $(-1.99)$ & & $(1.26)$ & & $(0.53)$ & & $(-3.25)$ \\
\hline
\end{tabular}




\begin{tabular}{ccccccccc} 
culdist & 0.0061 & 0.0044 & $0.0066^{* * *}$ & $0.0081^{* * *}$ & $-0.0029^{*}$ & -0.0015 & 0.0027 & 0.0036 \\
& $(1.58)$ & $(1.18)$ & $(3.34)$ & $(4.05)$ & $(-1.75)$ & $(-0.86)$ & $(0.97)$ & $(1.28)$ \\
Constant & $11.4840^{* * *}$ & $13.3820^{* * *}$ & $-4.5745^{* *}$ & -2.9276 & $-8.2072^{* * *}$ & $-8.1759^{* * *}$ & $6.7088^{* * *}$ & $5.4472^{* * *}$ \\
& $(6.74)$ & $(7.31)$ & -0.0024 & $(-1.28)$ & $(-7.64)$ & $(-7.31)$ & $(4.65)$ & $(3.42)$ \\
\hline Observations & 9044 & 9044 & 11977 & 11977 & 13216 & 13216 & 10659 & 10659 \\
$\mathrm{R}^{2}$ & 0.3542 & 0.3683 & 0.6073 & 0.6168 & 0.5503 & 0.5536 & 0.3126 & 0.3126 \\
\hline
\end{tabular}

\section{Concluding Remarks}

In contrast to the previous literature, we empirically analyzed the role of cultural factors in shaping the cross-border mobility of international students, using the data of 102 countries from 2000 to 2015 . We have used the export of cultural goods as a proxy for culture factors, perhaps for the first time in the literature. Our results indicate that culture factors are critical determinants of international student mobility. The export of cultural products is conducive to the increase of international students, in addition to international migration networks that have been found important in existing studies (Beine et al., 2014; Beech, 2015). However, the impacts of a common language and a common religion depend on the types of origin countries and destination countries. To be specific, international students choose to study in developing countries whose official language and religious beliefs are different from their home countries, while they tend to go to developed countries with common languages.

These results are relevant for the design of policies to attract foreign students, especially relevant for developing countries, such as China's B\&R Initiative. We propose that policy makers value the role of cultural factors in introducing international students. First, it provides an effective way to attract international students around the world, by expanding the exports of cultural goods. Second, the government could establish migration networks which can act as an information and cultural bridge between the destinations and origin countries. Third, it is especially critical for developing countries to cultivate their "soft power" such as unique customs, linguistic and religious cultures, raising their attractiveness to international students. Last but not 
least, as for developed countries, enhancing the popularity and global influence of their own languages are also effective.

We have devoted special attention to China, which has become the $3^{\text {rd }}$ largest host of international students in higher education and the biggest developing destination. Most foreign students come from South Korea, the U.S. and Southeastern Asian nations, and in recently years, more and more are coming from countries along the "belt \& road" due to government scholarships. As for Chinese outbound students, most of them choose English-speaking countries, especially the U.S., and neighboring countries Japan and South Korea. The former is due to the fact that English is the de-factor international language, and the latter for the business opportunities the two neighbors provide through their investments in and trade with China.

Finally a note of caution. We have not differentiated between the students for degree and those for non-degree studies, for two reasons. First, many developing countries in our sample lack the data for non-degree seeking students; Second, the number of non-degree seeking students in some developing countries is very small, which hardly makes sense in the regression analysis. As data become available in the future, research on them would be very fruitful. 


\section{References}

Beech, S. E. (2015). International student mobility: The role of social networks. Social \& Cultural Geography 16(3), 332-350.

Beine, M., Noel, R., and Ragot, L. (2014). Determinants of the International Mobility of Students. Economics of Education Review 41(8), 40-54.

Bouwel, V., Veugelers, R. (2013). The determinants of student mobility in Europe: the quality dimension. European Journal of Higher Education, 3(2), 172-190.

Brown, H. D. (1994). Principles of language learning and teaching (3rd Ed.). Englewood Cliffs, NJ: Prentice Hall Regents.

Caruso, R., Wit, H. D. (2015). Determinants of Mobility of Students in Europe: Empirical Evidence for the Period 1998-2009. Journal of Studies in International Education 19(3), 265-282.

Chen, T. M.,Barnett, G. A. (2000). Research on international student flows from a macro perspective: a network analysis of 1985, 1989 and 1995. Higher Education 39(4), 435453.

Chiswick, C. U. (2014). Immigrants and religion. IZA Discussion Paper, No. 8092.

D' Costa, A. P. (2006). The international mobility of technical talent: Trends and development implications. UNU World Institute for Development Economics Research (UNUWIDER), Research Paper No. 2006/143.

Disdier, A.C., Tai, S. H. T., Fontagné, L., and Mayer, T. (2010). Bilateral trade of cultural goods, Review of World Economics, 145(4), 575-595.

Falck, O., Heblich, S., Lameli, A., Südekum, J. (2012). Dialects, cultural identity, and economic exchange, Journal of Urban Economics 72(2), 225-239.

González, R. C., Mesanza, B. R., \& Mariel, P. (2011). The determinants of international student mobility flows: An empirical study on the Erasmus program. Higher Education, 62(4), 413-430.

Helpman, E., Melitz, M., \& Rubinstein, Y. (2008). Estimating trade flows: Trading partners and trading volumes. The Quarterly Journal of Economics 123(2), 441-487.

Hofstede, G., Hofstede, G. J., Minkov, M. (2010). Cultures and Organizations: Software of the Mind, Third Edition. McGraw-Hill Education, New York.

Iwabuchi, K. (2015). Pop-culture diplomacy in Japan: Soft power, nation branding and the question of international cultural exchange. International Journal of Cultural Policy 21(4), 419-432.

Jiang, W. (2000). Some people say that language is the mirror of culture, in the sense that people can see a culture through its language. Elt Journal 54(4), 328-34.

Kondakci, Y. (2011). Student mobility reviewed: Attraction and satisfaction of international students in Turkey. Higher Education 62(5), 573-592.

Liu, Q., Qiu, L.D., 2016. Intermediate input imports and innovations: Evidence from Chinese firms' patent filings, Journal of International Economics. 103, 166-183.

Liu, Y., Wang, H., Kong, F. S., 2013. Why do foreign students study in China, Journal of Higher Education 34 (5), 32-38.

Lowell, B. L., Khadka, P. (2008). International student mobility in a competitive world: Determinants and US Policy Before and After Post 9/11, Paper presented to the Population Association of America, New Orleans, April. 
Mazzarol T, Soutar G N. "Push-pull" factors influencing international student destination choice. International Journal of Educational Management 2002, 16(2): 82-90.

Mazzarol, T. W., Soutar, G. N. (2002). Push-pull factors influencing international student destination choice. International Journal of Education Management 16(2), 82-90.

Mcmahon, M. E. (1992). Higher education in a world market: A historical look at the global context of international study. Higher Education 24(4), 465-482.

OECD, 2017. Education at a Glance 2017, OECD Publishing, Pairs.

Otmazgin, N. K. (2012). Geopolitics and soft power: Japan's cultural policy and cultural diplomacy in Asia. Asia-Pacific Review 19(1), 37-61.

Park, E. L. (2009). Analysis of Korean students' international mobility by 2-D model: Driving force factor and directional factor. Higher Education 57(6), 741-755.

Qu, R. X., Li, J., Yang, X. (2016). An Empirical Study of the Effect of Cultural Identity on International Students in China. Economic Survey 33(3), 48-53.

Racine, A., Villeneuve, P. Y., \& Thériault, M. (2003). Attracting foreign students: The case of two universities in Québec. Journal of Studies in International Education 7(3), 241-252.

Scheffler, S. (2007). Immigration and the significance of culture, Philosophy \& Public Affairs $35(2), 93-125$.

Solimano, A. (2008). The international mobility of talent: Types, causes, and development impact. Oxford University Press.

UNESCO, 2018. Global Education Monitoring Report 2017/2018, Pairs.

UNESCO, 2019. Global Education Monitoring Report 2019, Pairs.

Wang, Q., Hannes, K. (2014). Academic and socio-cultural adjustment among Asian international students in the Flemish community of Belgium: A photo voice project. International Journal of Intercultural Relations 39, 66-81

Wei, H., Yuan, R., Lai, D. S. (2018). An Empirical Study on the Determinants of International Students to China. Educational Research 466 (11), 76-90.

Zheng, X. H. (2003). Research on China's Foreign Cultural Exchange in Higher Education. Beijing: Minzu Press. 